\title{
Effects of fluoride and Aloe vera tooh gel in artificial white spot lesions in vitro
}

\author{
Efeito dos cremes dentais à base de flúor e Aloe vera na lesão artificial de mancha branca in vitro
}

Tânia Mara da SILVA'

Beatriz Maria da FONSECA ${ }^{1}$

Ana Luísa Leme Simões SALES ${ }^{1}$

Priscila HOLLEBEN ${ }^{1}$

Márcia Carneiro VALERA ${ }^{1}$

Maria Amélia Máximo de ARAÚjo'

\section{ABSTRACT}

\section{Objective}

The aim of this study was to evaluate the effects of toothbrushing using a fluoride toothpaste and Aloe vera tooth gel on artificial white spot lesions through the Knoop microhardness (KHN) analysis.

\section{Methods}

Sound bovine enamel samples (2 mm/diameter and $2 \mathrm{~mm} /$ depth) were prepared and immersed in artificial white spot lesion for $24 \mathrm{~h}$. The preparation of artificial white spot lesions was performed by $\mathrm{pH}$-cycling process. The samples were randomly divided into two groups ( $n=20$ ), according the dentifrice used: containing fluoride (Colgate Total 12) or Aloe vera (Forever Bright Aloe Vera Toothgel). The top surface of samples was submitted to 10,000, 25,000, 50,000 and 100,000 brushing cycles (200 g load) in an automatic brushing machine with abrasive slurry. The KHN analysis were evaluated at baseline, after immersion in artificial white spot lesion and after 10,000, 25,000, 50,000 and 100,000 cycles of brushing. Data were analyzed by two-way repeated measures ANOVA and Tukey tests $(p=0.05)$.

\section{Results}

The KHN values significantly increased after brushing cycles compared to demineralized means. No significant differences showed for dentifrice factor ( $p=0.263)$. However, there were statistically significant differences between groups in cycles of brushing times ( $p=0.0001)$.

\section{Conclusion}

The toothpastes (containing fluoride or Aloe vera) were effective in increasing the superficial microhardness of artificial white spot lesions.

Indexing terms: Aloe. Dental enamel. Toothpastes.

\section{RESUMO}

\section{Objetivo}

Avaliar o efeito da escovação simulada usando creme dental com flúor e Aloe vera em lesão de mancha branca artificial in vitro, através da análise da microdureza Knoop (KHN).

\section{Métodos}

Amostras de esmalte bovino ( $2 \mathrm{~mm} /$ diâmetro e $2 \mathrm{~mm} /$ altura) foram preparados e imersos em solução artificial de cárie por $24 \mathrm{~h}$. 0 preparo para indução de lesão de mancha branca foi realizado por processo de ciclagem de pH. As amostras foram aleatoriamente divididas em dois grupos ( $n=20)$, de acordo com o dentifrício utilizado: creme dental contendo flúor (Colgate Total 12) ou creme dental à base de Aloe vera (Forever Bright Aloe Vera Toothgel). A superfície das amostras foi submetida à 10.000, 25.000, 50.000 e 100.000 ciclos de escovação simulada (200 g/peso) em uma máquina de escovação. A análise de microdureza (KHN) foi realizada inicialmente, após o período de imersão em solução artificial de mancha branca e após 10.000, 25.000, 50.000 e 100.000 ciclos de escovação. Os dados foram submetidos aos testes RM-ANOVA dois fatores e Tukey $(p=0.05)$.

\section{Resultados}

Os valores de KHN aumentaram significantemente após os ciclos de escovação, quando comparado aos valores após a imersão em solução desmineralizante. Não houve diferenças estatisticamente significantes entre os cremes dentais ( $p=0.263)$. Entretanto, em relação aos ciclos de escovação, houve diferenças significantes $(p=0001)$.

\section{Conclusão}

Os cremes dentais (contendo flúor ou Aloe vera) foram efetivos no aumento da microdureza superficial em lesão artificial de mancha branca.

Termos de indexação: Aloe. Esmalte dentário. Creme dental.

\footnotetext{
${ }^{1}$ Universidade Estadual Paulista Júlio de Mesquita Filho, Instituto de Ciência e Tecnologia de São José dos Campos, Departamento de Odontologia Restauradora. Av. Engenheiro Francisco José Longo, 777, Jardim São Dimas, 12245-900, São José dos Campos, SP, Brasil. Correspondência para / Correspondence to: TM SILVA. E-mail: <taniamara.odonto@gmail.com>.
} 


\section{INTRODUCTION}

The dental caries is a pathological process of microbiological etiology resulting in the local destruction of dental tissues by the dissolution of the mineral phase (mainly constituted by hydroxyapatite crystals) by organic acids from the bacterial fermentation. The bacteria that have been associated to caries are the Streptococcus of mutans groups (which include the species Streptococcus mutans and Streptococcus sobrinus), Lactobacillus spp. and among others microorganisms favored by the cariogenic conditions promoted by Streptococcus of mutans groups, such as yeasts Candida albicans, capable of surviving and proliferating in acid media'.

Characterized by an imbalance of the demineralization-remineralization processes (DE-RE), the caries disease is initiated by DE of the enamel surface. The acids fermented by the cariogenic bacteria are diffused within the enamel and dissociated in hydrogen ion $\left(\mathrm{H}^{+}\right)$, promoting the reduction of the $\mathrm{pH}$ of the medium, as well as the dissolution of calcium phosphate from the tissues, consequently with structural loss².

The visible initial alterations are displayed as opaque areas (white spots) in enamel, subject to $\mathrm{RE}^{3}$. Researchers have demonstrated the development and stopping of initial lesions of white spot in human enamel and the possibility of their RE 4 .

Artificial caries lesions may be reproduced in vitro on enamel surface, simulating the main histological features of natural caries ${ }^{5}$. Compared to the natural lesions of the subsuperficial deepness, the initial lesions of white spots are more easily reproducible and because of its homogeneity, they enable the use of several areas of surface for laboratorial tests of RE.

In vitro models of $\mathrm{pH}$ cycling enable to: evaluate the alterations in the tooth structure promoted by the mineral gain or loss; simulate the natural process of caries occurring within oral cavity; and assess the anticaries potential of fluoride dentifrices and mouthrinses. According to previous study, the use of $\mathrm{pH}$ cycling models is the best way to simulate the dynamics of tooth caries in in vitro studies ${ }^{6}$.

Some authors have reported the correlation between DE and the reduction of the superficial microhardness ${ }^{7}$. The superficial microhardness is a physical property that enables to study the effects of some physical and chemical agents on the enamel, dentin, and cementum surface ${ }^{8}$. Both the decrease and the increase of the enamel hardness shows an linear relationship with $D E$ and $R E$, that is, the microhardness measurements may be used as indicators of the mineralization degree of dental tissues ${ }^{9}$.

Since the discovery of fluoride as a therapeutic agent for tooth caries prevention, it has been largely employed in Dentistry (gels, varnishes, dentifrices and mouthrinses) and incorporated within water and food (salt, milk, juices, soft drinks, fluoride supplements).

Currently, the use of natural products in the prevention and treatment of oral diseases has been increasing in rural and urban areas ${ }^{10}$. Among the numerous plants with therapeutic potential, Aloe Barbadensis Miller - commonly known as Aloe vera -, has been used as phytotherapeutic agent because of its antimicrobial, anti-inflammatory, antioxidants and healing properties ${ }^{11}$. Additionally, it shows an antiplaque effect used as dentifrice constituted by $35 \%$ Aloe vera pure gel stabilized with $0.1 \%$ propolis.

Propolis is capable of inhibiting the action of a great spectrum of cariogenic bacterias, i.e. S. mutans, and it is an agent with large anticaries and antiperiodontitis action ${ }^{12-15}$. In vitro studies have demonstrated the antimicrobial effect of an Aloe vera based dentifrice, which promoted the growth inhibition of several oral microorganisms, such as S. mutans, S. sanguis, A. viscosus and C. albicans ${ }^{16-17}$. In another clinical study, the Aloe vera based dentifrice did not show any additional effect neither on plaque nor gingivitis compared with the fluoride dentifrice ${ }^{11}$. Although different studies discussed about the benefits of Aloe vera tooth gel in oral conditions, the effects of toothbrushing using Aloe vera based dentifrice on the initial caries lesions must be reported.

Thus, the aim of this study was to evaluate the effects of toothbrushing using a fluoride toothpaste and Aloe vera tooth gel on artificial white spot lesions through the Knoop microhardness analysis. The null hypothesis tested was that the toothbrushing using Aloe vera tooth gel is not able to promote the same effect of fluoride toothpaste on artificial white spot lesions.

\section{METHODS}

\section{Samples preparation}

Forty sound bovine incisors were used to obtain enamel samples. The bovine incisors were obtained following a protocol approved by University Ethic Research Committee.

The enamel cylinders $(3 \mathrm{~mm} /$ diameter and 2 $\mathrm{mm} /$ height) were obtained using a trephine bur ( $3 \mathrm{~mm}$ in 
diameter) with $1 \mathrm{~mm}$ of enamel and $1 \mathrm{~mm}$ of dentin. The dentin surfaces were performed with 600 grit aluminum oxide abrasive disks (Extec, Enfield, CT, USA) to standardize the depth of the samples. The enamel surfaces were polished in a polishing device (DP-10, Panambra Industrial e Técnica, São Paulo, Brazil) using a sequence of 1200, 2400 and 4000 grit aluminum oxide abrasive disks (Extec, Enfield, CT, USA). All specimens were stored in deionized water at $4^{\circ} \mathrm{C}$, up to the time of initial microhardness analysis.

\section{Artificial white spot lesion}

The artificial white spot lesions were prepared according to the protocol proposed by Queiroz and others ${ }^{18}$. The demineralizing solution consisted of $0.05 \mathrm{M}$ acetate, 1.3 $\mathrm{mM}$ of calcium, $0.78 \mathrm{mM}$ of phosphate and $0.0315 \mathrm{ppm} \mathrm{F}$, adjusted to a $\mathrm{pH}$ of 5.0. The $\mathrm{pH}$ assessment was performed through a pHmeter (DM-20, Digimed, SP, Brazil).

The dentinal base of each sample was painted with two layers of an acid-resistant nail varnish (Risqué, Cosmed Indústra de Cosmético e Medicamento, SP, Brazil), except the enamel surface. The samples were kept in individual supports (Eppendorf, SP, Brazil) with $2 \mathrm{ml}$ of demineralizing solution for $24 \mathrm{~h}$, at $37^{\circ} \mathrm{C}$. After this period, the samples were washed thoroughly, and stored into deionized water for $24 \mathrm{~h}$, at $37^{\circ} \mathrm{C}$, up to the time of the second surface microhardness analysis.

\section{Brushing protocols}

The enamel surfaces were subjected to brushing abrasion in an automatic brushing machine (Odeme Biotechnology, SC, Brazil) which imparted reciprocating motion to 6 soft and straight bristle toothbrush heads (Curaprox 5460 Ultra Soft, Curaden Swiss do Brasil Imp. Exp. Ltda, SP, Brazil). This machine provides linear brushing movements across the samples at a speed of 120 cycles per min at $37^{\circ} \mathrm{C}$, with a double pass of the brush head over the surface, under a vertical load of $200 \mathrm{~g}$ with dentifrice slurry. The dentifrice slurry consisted of dentifrice and deionized water, in a ratio of 1:3, by weight ${ }^{19}$. The dentifrices employed and their compositions were specified in Table 1.

Table 1. Composition of the dentifrices tested.

\begin{tabular}{|c|c|}
\hline Dentifrice & Composition \\
\hline $\begin{array}{l}\text { Colgate Total } 12 \\
\text { (Colgate Palmolive } \\
\text { Co.) }\end{array}$ & $\begin{array}{l}\text { Sodium monofluorophosphate ( } 1450 \\
\text { ppm), sodium hydroxide, } 0.3 \% \text { triclosan, } \\
\text { sodium lauryl sulfate, moist, thickener, } \\
\text { sorbitol, water and hydrated silica. }\end{array}$ \\
\hline $\begin{array}{l}\text { Forever Bright Aloe } \\
\text { Vera Tooth gel (Forever } \\
\text { Living Products Brazil } \\
\text { Ltda.) }\end{array}$ & $\begin{array}{l}\text { Aloe barbadensis gel, sorbitol, hydrated } \\
\text { silica, glycerin, sodium lauryl sulfate, } \\
\text { sodium benzoate and bee propolis, } \\
\text { fluoride-free. }\end{array}$ \\
\hline
\end{tabular}

The top of enamel surfaces were submitted to 10,000 cycles of brushing for $90 \mathrm{~min}, 25,000$ cycles of brushing for $4 \mathrm{~h} 15 \mathrm{~min}, 50,000$ cycles of brushing for $7 \mathrm{~h} 30 \mathrm{~min}$ and a total of 100,000 cycles of brushing for $15 \mathrm{~h}$, simulating 4,2 years of brushing in oral cavity $^{20}$. After each cycles of brushing, the samples were kept into deionized water at $37^{\circ} \mathrm{C}$, up to the time to microhardness analysis.

\section{Knoop microhardness measurements}

The microhardness measurement was performed with a microhardness tester (FM-700, Future Tech Company, Tokyo, Japan), Knoop tip, under $50 \mathrm{~g}$ load for $15 s^{21}$. Three indentations were performed 100 $\mu \mathrm{m}$ apart from each other, at the surface of enamel samples. The means values were determined as Knoop Hardness Number (KHN) and their increase or reduction means, respectively, the remineralization (mineral gain) or demineralization (mineral loss) of the ename ${ }^{22}$.

The Knoop microhardness was measured onto the sound enamel surface (at baseline time), after the artificial white spot lesion (DE) and after 10,000, 25,000, 50,000 and 100,000 cycles of brushing.

\section{Statistical analysis}

The experimental variables under study were dentifrices (Forever Bright Aloe Vera Tooth gel and Colgate Total 12) and times (at baseline, after artificial white spot lesion-DE, after 10,000, 25,000, 50,000 and 100,000 cycles of brushing). The variable response was the average of three microhardness measurements.

Data were submitted to statistical analysis using the computer program Minitab (version 16.1, Minitab, 2010), Statistix (version 8.0, Analytical Software, 2003) and Statistica (version 9.1, StatSoft, 2010). The inferential statistics consisted of two-way repeated measures ANOVA (dentifrices and times), followed by Tukey's test. The level of significance was the conventional value of $5 \%(p<0.05)$.

\section{RESULTS}

The KHN means values and standard deviation is shown in Table 2. Regarding the different times, the KHN values significantly increased after brushing cycles compared to DE means. The application of RM-ANOVA showed significant differences for the time factor $(p=0.0001)$. However, no significant differences showed for dentifrice factor $(p=0.263)$. 
Table 2. Means $( \pm S D)$ of KHN and Tukey tests for the dentifrices and times.

\begin{tabular}{lcc}
\hline Times & Colgate Total 12 & Forever bright aloe vera tooth gel \\
\hline Baseline & Mean \pm SD & Mean \pm SD \\
DE & $257.0 \pm 80.4 \mathrm{BC}$ & $305.5 \pm 75.8^{\mathrm{AB}}$ \\
10,000 cycles & $147.9 \pm 28.5 \mathrm{E}$ & $149.4 \pm 43.3^{\mathrm{E}}$ \\
25,000 cycles & $165.1 \pm 57.6 \mathrm{DE}$ & $193.5 \pm 61.4^{\mathrm{DE}}$ \\
50,000 cycles & $190.5 \pm 51.0 \mathrm{DE}$ & $195.8 \pm 62.8^{\mathrm{CDE}}$ \\
100,000 cycles & $286.8 \pm 65.0 \mathrm{AB}$ & $218.6 \pm 45.3^{\mathrm{CD}}$ \\
\hline
\end{tabular}

Note: Different letters means significant differences among groups $(p<0.05)$.

The DE groups were statistically different at brushing cycles. Colgate and Aloe vera tooth gel showed the similar KHN values at DE time. Also, it was observed that after 10,000 cycles of brushing, both groups showed higher KHN values than DE time.

There were statistically significant differences between groups in cycles of brushing times. Aloe Vera tooth gel exhibited KHN values higher than those of Colgate at $10,000,25,000$ and 100,000 cycles of brushing.

\section{DISCUSSION}

Aloe vera (Aloe barbadensis) used as a gel has complex mixture of chemical composition. The synergic effect of these components in Dentistry is still not clear. Its gel is composed of $98-99 \%$ of water and $1-2 \%$ of active components (anthraquinones, naftoquinones, flavonoids, polysaccharides, essential amino acids and vitamins), which are highly variable according to the specie and growth conditions of the plant ${ }^{23}$.

Among the essential amino acids Aloe vera gel, arginine is the most abundant. Within the gel, it is also found the salicylic acid, uronic acid and galacturonic acid; fructose, mannose, glucose and other hydrolysable sugars; enzymes as oxidase, amylase and catalase; sodium, potassium, calcium and magnesium ${ }^{24}$. The hard and mineralized enamel surface is porous and may enable the passage of ions, such as sodium, potassium, magnesium and calcium. Therefore, the remineralizing capacity of the Aloe vera based dentifrice, constituted of $35 \%$ of pure gel, could be attributed to the deposition of arginine associated to the calcium on the enamel surface.

When the enamel surface is exposed to acids formed by bacterial metabolism, the minerals are removed from the hydroxyapatite crystals, causing in increase in intercrystalline spaces and porosity in the surface. The visible initial alterations are displayed as opaque areas (white spot lesions), which can be remineralized ${ }^{25}$. In previous studies, the enamel surface submitted a demineralization solution for 24 hours showed decrease in brightness of surface and microscopically some changes on its surface similar to initial caries lesion ${ }^{26}$.

In this present study, white spot lesions in enamel were artificially produced by demineralizing solution $(\mathrm{pH}=5)$, instead of oral isolates of $\mathrm{S}$. mutans. The biofilm on the enamel surface was initially removed by the polishing of the specimens, and brushing cycles prevented the establishment of a new biofilm. Both dentifrices employed in this study showed in their composition sodium lauryl sulphate that has an emulsifier action and promotes a moderate antiplaque effect ${ }^{11}$. Additionally, the Aloe vera based dentifrice has propolis in its composition, which also has an antiplaque potential. Moreover, some authors concluded that Aloe vera gel, at optimum concentration in either dentifrices or mouthrinses, is effective in preventing the caries diseases ${ }^{13,23}$.

The results of Knoop microhardness in this study demonstrated that Aloe vera based dentifrice (Forever Bright Aloe Vera Toothgel) is as effective as the fluoride dentifrice (Colgate Total 12) on artificial white spot lesions in enamel. These findings are in agreement with a previous study that observed Aloe vera toothpaste gel (Forever Bright) was equally effective as two popular commercial toothpastes ${ }^{17}$. Thus, the null hypothesis of the present study was rejected.

Regarding brushing cycles, it is observed that after 10,000 cycles of brushing in both dentifrices were significantly effective on artificial white spot lesions compared to the demineralized group. At 50,000 cycles 
of brushing, the fluoride dentifrice differs significantly from the Aloe vera tooth gel. Colgate Total 12 showed $\mathrm{KHN}$ values greater than baseline values, remaining these values without significant differences until 100,000 cycles. After 100,000 cycles of brushing, both dentifrice Aloe vera and Colgate Total 12 - exhibited microhardness values as same as the baseline time, which showed the effectiveness of the both dentifrice in treatment of white spot lesion. In a previous clinical trials, Aloe vera toothpaste did not show any significant differences from fluoridated dentifrices for the control and reduction of dental plaque and gingivitis ${ }^{11}$.

It is highlighted that fluoride and Aloe vera are incompatible because the therapeutic potential of Aloevera is lost together with fluoride. Aloe vera based dentifrice is also less abrasive than the fluoride dentifrice ${ }^{17}$. However, the majority of the antimicrobial effects of commercially available toothpastes can be attributed to their fluoride content, in the form of sodium monoflourophosphate (a concentration of $500-1,000 \mathrm{ppm})^{17}$. The Aloe vera tooth gel used in this study has no added fluoride content but it exhibits the same antimicrobial effect on artificial white spot lesions that conventional toothpaste with fluoride content.

It is known that the fluoride applied onto the tooth surface reduces the enamel solubility in acid medium, which inhibits demineralization and accelerates remineralization. Additionally, it has bactericidal and bacteriostatic effects depending on its concentration, but the excessive ingestion of fluoride during the period of tooth formation causes fluorosis.

Dental fluorosis is a result of excessive fluoride ingestion during enamel development, which for the permanent teeth occurs in childhood between 2 to 8 years old ${ }^{27}$. The use of fluoride in preventive dentistry has been the most effective in carious lesions, but it also associated with the increasing prevalence of dental

\section{REFERENCES}

1. Marsh PD. Plaque as a biofilm: pharmacological principles of drug delivery and action in the sub- and supragingival environment. Oral Dis. 2003;9 Suppl 1:16-22. doi: 10.1034/j.16010825.9.s1.4.x

2. Robinson C, Shore RC, Brookes SJ, Strafford S, Wood SR, Kirkham J. The chemistry of enamel caries. Crit Rev Oral Biol Med. 2000;11(4):481-95. doi: 10.1177/10454411000110040601 fluorosis in many countries. Some authors reported that there were chances of mild fluorosis in children, especially younger than 6 years, who ingested large amounts of fluoride from reconstituted concentrate infant formulas and fluoridated dentifrice $28-30$

Therefore, to minimize the risk of developing fluorosis while maximizing the caries-prevention, the Aloe vera based dentifrice (without fluoride) would be an alternative to oral hygiene, especially in children younger than 6 years old. More studies should be done in order to clarify the mechanism of remineralization of Aloe vera tooth gel on the demineralized enamel surface.

Thus, Aloe vera based dentifrice is effective in preventing the white spot lesion as same as a conventional fluoride dentifrice and it would be an option for toothbrushing in children under the age of six.

\section{CONCLUSION}

Based on the methodology proposed, it can be concluded that the toothpastes containing fluoride or Aloe vera were effective in increasing the superficial microhardness of artificial white spot lesions.

\section{Collaborators}

TM SILVA participated in methodology, statistical analysis and the writing of the paper. BM FONSECA participated in the development of the methodology, laboratorial tests and in the writing of the manuscript. ALLS SALES collaborated in the laboratory part and writing of the paper. P HOLLEBEN collaborated during experimental and statistical analysis, as well as writing part. MC VALERA was responsible for the research proposed, methodological development and the writing of this study. MAM ARAUJO was also responsible for this study and participated during the experimental design and writing of the paper.

3. Baldissera RA, Dias JC, Busato AL. Remineralization of incipient caries.Clinical evaluation of Reminer in treatment of white lesions. RGO, Rev Gaúch Odontol. 1987:35(5):388-91.

4. Santa Cruz ME, Santos RA, Santos VIM. Tratamento de cáries incipientes. RGO, Rev Gaúch Odontol. 1991;39(4):257-64.

5. Gohring TN, Zehnder M, Sener B, Schmidlin PR. In vitro microleakage of adhesive-sealed dentin with lactic acid and saliva exposure: a radio-isotope analysis. J Dent. 2004;32(3):23540. doi: 10.1016/j.jdent.2003.11.003 
6. ten Cate JM, Duijsters PP. Influence of fluoride in solution on tooth demineralization. I. Chemical data. Caries Res. 1983;17(3):193-9.

7. Featherstone JD. Prevention and reversal of dental caries: role of low level fluoride. Community Dent Oral Epidemiol. 1999;27(1):31-40. doi: 10.1111/j.1600-0528.1999.tb01989.x

8. Jabbarifar SE, Tabibian SA, Poursina F. Effect of fluoride mouthrinse and toothpaste on number of streptococcal colony forming units of dental plaque. J Res Med Sci. 2005;10(6):3637.

9. Koulourides T, Sims RM. Artificial caries studied with intermittent demineralizing and mineralizing treatments of teeth. Ala J Med Sci. 1967;4(3):282-8.

10. Botelho MA, Nogueira NA, Bastos GM, Fonseca SG, Lemos TL, Matos FJ, et al. Antimicrobial activity of the essential oil from Lippia sidoides, carvacrol and thymol against oral pathogens. Braz J Med Biol Res. 2007;40(3):349-56. doi: 10.1590/S0100$879 \times 2007000300010$

11. de Oliveira SM, Torres TC, Pereira SL, Mota OM, Carlos MX. Effect of a dentifrice containing Aloe vera on plaque and gingivitis control. A double-blind clinical study in humans. J Appl Oral Sci. 2008;16(4):293-6. doi: 10.1590/\$1678-77572008000400012

12. Bertolini PF, Biondi Filho O, Pomilio A, Pinheiro SL, Carvalho MS. Antimicrobial capacity of Aloe vera and propolis dentifrice against Streptococcus mutans strains in toothbrushes: an in vitro study. J Appl Oral Sci. 2012;20(1):32-7. doi: 10.1590/S167877572012000100007

13. Valera MC, da Rosa JA, Maekawa LE, de Oliveira LD, Carvalho CA, Koga-Ito CY, et al. Action of propolis and medications against Escherichia coli and endotoxin in root canals. Oral Surg Oral Med Oral Pathol Oral Radiol Endod. 2010;110(4):e70-4. doi: 10.1016/j.tripleo.2010.01.029

14. Doddanna SJ, Patel S, Sundarrao MA, Veerabhadrappa RS Antimicrobial activity of plant extracts on Candida albicans: an in vitro study. Indian J Dent Res. 2013;24(4):401-5. doi: 10.4103/0970-9290.118358

15. Kim MJ, Kim CS, Kim BH, Ro SB, Lim YK, Park SN, et al. Antimicrobial effect of Korean propolis against the mutans streptococci isolated from Korean. J Microbiol. 2011;49(1):1614. doi: 10.1007/s12275-011-1002-8

16. Lee SS, Zhang W, Li Y. The antimicrobial potential of 14 natural herbal dentifrices: results of an in vitro diffusion method study. J Am Dent Assoc. 2004;135(8):1133-41.

17. George D, Bhat SS, Antony B. Comparative evaluation of the antimicrobial efficacy of aloe vera tooth gel and two popular commercial toothpastes: an in vitro study. Gen Dent. 2009;57(3):238-41.

18. Queiroz CS, Hara AT, Paes Leme AF, Cury JA. pH-cycling models to evaluate the effect of low fluoride dentifrice on enamel de- and remineralization. Braz Dent J. 2008;19(1):21-7. doi: 10.1590/ S0103-64402008000100004
19. Turssi $C P$, Hara $A T$, de Magalhaes $C S$, Serra MC, Rodrigues $A L$, Jr. Influence of storage regime prior to abrasion on surface topography of restorative materials. J Biomed Mater Res B Appl Biomater. 2003;65(2):227-32. doi: 10.1002/jbm.b.10005

20. Heath JR, Wilson HJ. Abrasion of restorative materials by toothaste. J Oral Rehabil. 1976:3(2):121-38. doi: 10.1111/ j.1365-2842.1976.tb00936.x

21. de Paula $A B$, de Fucio $S B$, Alonso RC, Ambrosano GM, Puppin-Rontani RM. Influence of chemical degradation on the surface properties of nano restorative materials. Oper Dent. 2014;39(3):E109-17. doi: 10.2341/12-340

22. Koo H, Cury JA. In situ evaluation of a dentifrice containing MFP/ DCPD on fluoride uptake and remineralization by human dental enamel. Rev Odontol Univ São Paulo. 1999;13(3):245-9.

23. Fani M, Kohanteb J. Inhibitory activity of Aloe vera gel on some clinically isolated cariogenic and periodontopathic bacteria. J Oral Sci. 2012;54(1):15-21. doi: 10.2334/josnusd.54.15

24. Grindlay D, Reynolds T. The Aloe vera phenomenon: a review of the properties and modern uses of the leaf parenchyma gel. J Ethnopharmacol. 1986;16(2-3):117-51.

25. Thylstrup A, Fejerskov O. Cariologia clínica. $2^{a}$ ed. São Paulo: Santos; 1995.

26. Lynch RJ, Ten Cate JM. The effect of lesion characteristics at baseline on subsequent de- and remineralisation behaviour. Caries Res. 2006;40(6):530-5. doi: 10.1159/000095653

27. Aoba $T$, Fejerskov O. Dental fluorosis: chemistry and biology. Crit Rev Oral Biol Med. 2002;13(2):155-70. doi: 10.1177/154411130201300206

28. Wright JT, Hanson N, Ristic H, Whall CW, Estrich CG, Zentz RR. Fluoride toothpaste efficacy and safety in children younger than 6 years: a systematic review. J Am Dent Assoc. 2014;145(2):1829. doi: 10.14219/jada.2013.37

29. Zohoori FV, Duckworth RM, Omid N, O'Hare WT, Maguire A Fluoridated toothpaste: usage and ingestion of fluoride by 4- to 6-yr-old children in England. Eur J Oral Sci. 2012 Oct;120(5):41521. doi: 10.1111/j.1600-0722.2012.00984.x

30. Levy SM, Broffitt B, Marshall TA, Eichenberger-Gilmore JM, Warren JJ. Associations between fluorosis of permanent incisors and fluoride intake from infant formula, other dietary sources and dentifrice during early childhood. J Am Dent Assoc. 2010;141(10):1190-201. 